\title{
Buddhist Philosophy of Mind: Nāgārjuna's Critique of Mind-Body Dualism From His Rebirth Arguments ${ }^{1}$
}

Sonam Thakchoe

Philosophy and Gender Studies Department

School of Humanities

University of Tasmania

sonam.thakchoe@utas.edu.au

Buddhism as Mind-Body Dualism

Richard Hayes (1993, p. 2013) and Dan Arnold (2008, p. 2012) have made the claim that Dharmakīrti is a mind-body dualist by virtue of his doctrine of rebirth. Dharmakīrti offers “the Buddhist tradition's most complete defences of rebirth, advanced some of this tradition's most explicitly formulated arguments for mind-body dualism” (Arnold 2008, p. 1079). Arnold identifies Dharmakīrti as an exemplar Buddhist philosopher who defends Buddhist reductionism and mind-body dualism. On Dharmakīrti's view, argues Arnold, the dynamic and relational character of subjectivity is not in conflict with the view that amongst the psychophysical components of phenomenological persons, are constitutively mental aggregates - feeling, perception, dispositions, awareness - whose activities such as anxiety, fears, desires, imaginations, memories, will, intention, although arising from physical aggregates, are nonetheless not reducible to physical events. But because "mental events cannot supervene upon physical event - [Dharmakīrti] is unmistakably dualist" (2008, p. 1088). He adds further "it is clear, rather, that Dharmakīrti's arguments for rebirth press a case for a strongly ontological sort of dualism" (Arnold 2012, p. 42). Hayes takes Arnold's ontologically thin dualism one step further, defending an ontologically thicker form of mindbody dualism according to which mind is separate from the body and can thus be related presently with one physical body and in the future with another. This supposition, Hayes argue, must be made if Dharmakīrti's doctrine of rebirth is to make sense because without 
having a commitment to a version of mind-body dualism, "the majority of Buddhist doctrines that presuppose rebirth would be mostly incoherent" (Hayes 2013, p. 395). The reason for this is that if there is no rebirth requiring the separation of mind and body, "then the very goal of attaining nirvāna, understood as the cessation of rebirth, becomes almost perfectly meaningless" (Hayes 1993, p. 128). In other words, Hayes' claim is that without some form of commitment to rebirth embedded in a version of mind-body dualism, nirvāna which is the goal that Buddhists seek to achieve becomes automatically available to all who die, irrespective of how they may have lived. But for the theory of rebirth to make sense, Hayes claims; Dharmakīrti must hold that mind and body are two separate substances, only then would it be able to justify the supposition that the same mind can associate now with one body and in the next life with another; and in fact that the mind must be propelled between bodies until enlightenment is achieved ending the cycle of rebirths (Hayes 2013: p. 395).

Hayes' paper does not explicitly attribute to Dharmakīti any one form of mind-body dualism in particular. However, if my interpretation of Hayes' position is correct, the form of mind-body dualism he is attributing to Dharmakirti appears strikingly similar to the ontologically thick sort of dualism (in contrast with Arnold's ontologically thin sort of dualism), that we find in Brahmanical schools, the metaphysical view that persons have two fundamentally and irreducibly different properties of which the mind is the persistent and the body the non-persistent.

Hayes claims Dharmakīrti is committed to mind-body dualism by virtue of his belief in rebirth: that he holds the mind and body are separate entities, of which the mind or consciousness is the same surviving or persistent entity and the body in which its resides continually undergo changes, thus, is different in different lives. Notice, though, Hayes himself does not use the terms "same" or "persistent" to describe the mind, but he comes very close when he does use the term "changing" to describe the body against which he contrasts 
the mind. And he also does explicitly assert that the mind "survives" the death of the physical body whereas the body naturally does not persist or "does not survive" its death. Based on the supposition that it is the same persistent mind, he goes on to claim: "it must be supposed that the mentality is separate from the physical body and can therefore be associated now with one physical body and now with another" (Hayes 2013, p. 395 Italics added). Here Hayes is implicitly claiming that for Dharmakīrti's rebirth theory to make sense, he must posit mind as the same persistent entity separate from the body which undergoes change, and therefore, must be different in each life. Only when Dharmakîrti holds the mind to have the same persistent nature, on Hayes account, could it be said to have a relationship with one type of body now in this life and with another in the future life.

Assuming that Hayes' reading of Dharmakīrti is correct, we can reconstruct the mindbody dualism argument which Hayes attributes to Dharmakīrti as follows:

1. My body does not survive after death.

2. My mind survives the death of an old material body and takes on a new future material body.

3. Therefore, rebirth occurs since my mind can be associated presently with one body and in the future with another. (1, 2 modus pollens $)$

4. It follows; therefore, mind and body are distinct. (1, 2, 3 modus pollens)

Let us suppose that Hayes is right that Dharmakīrti asserts a theory of rebirth which requires a separation of the mind and the body and that Dharmakīrti seeks its cessation (nirvāna), that is, the cessation of the belief that the mind is separate from the body (as its soteriological goal). There are three immediate absurd consequences Dharmakīrti faces.

First, according to the Mahāyāna Buddhist arhats, ārya-bodhisattvas, and buddhas have already attained nirvāṇa (they are all "enlightened beings") and have done so because they are supposed to have been liberated from the conditions that bind themselves to the 
repeated cycle of samsāric births and deaths. A condition which brings about rebirth, on Dharmakīrti's account, would be no other than the separation of mind and body; his claim is that because mind is separate from the body, rebirth occurs. It follows from his claim; that nirvāna is a freedom from the unity of mind and body, and thus that any living enlightened being who has attained nirvāṇa, on his account, cannot be an embodied being - she must be either wholly body (with no mind), or wholly mind (with no body), or neither of the two (having neither the mind nor the body). The enlightened Buddha, on Dharmakirti's analysis, ought to be regarded as either purely a physical being (absent mental states) or purely a mental being (absent any physical body), or a being with neither any physical body nor any mental states.

Second, it is not clear how Mahāyāna Buddhist's could explain the claim that awakened beings repeatedly return to the world for the welfare of other beings. There seem to be only three equally problematic options available for Mahāyāna Buddhism if Dharmakīrti's claim is correct. It should either assume that those awakened beings - bodhisattvas and buddhas - are just bodies without minds, or just minds without bodies, or neither (absent of both bodies and minds). The fourth possible option is the standard Mahāyāna view according to which awakened beings who already attained nirvāṇa have done so because they perfected both the physical qualities of rūpakāya and the mental qualities of dharmakāya. Yet this fourth option will not be available for the Mahāyānist to advance; because, on Dharmakīrti's mind-body dualist account, liberation precisely entails freedom from that of mind-body duality. Hence the standard position will not be available for Mahāyāna Buddhism to justify the reasons awakened beings are able to return to the world equipped with both mental and physical properties.

Third, it would absurdly follow from Dharmakīrti's thesis that nirvāṇa is available to anyone who rejects mind-body dualism; after all it is in virtue of holding this view that 
beings are prevented from becoming liberated. Consequently, on Dharmakīrti's account of rebirth, liberation would be available to anyone who decidedly adopts monism (e.g., materialism of the classical Indian Cārvāka type or physicalism of the modern philosophers). There are various alternative theories of mind-body dualism including substance dualism, property or event dualism, or vitalism. So what type of dualism does Dharmakīrti espouse? In other words, which version of dualism in particular could hold more promising parallels in capturing Dharmakīrti's position? If, however current Buddhist philosophical scholarship is correct about Buddhism's overall anti-substantialism, it is unlikely that Hayes and Arnold would be charging Dharmakīrti with advocating 'substance' dualism to justify its rebirth theory. It would be counterintuitive to claim that Dharmakinti might be invoking the sort of Cartesian mind-body dualist proof to explain his theory of rebirth. It is already widely recognized within Buddhist studies, by philosophers including Jay Garfield (2015), The Cowherds (2011, 2016), Dan Arnold (2012), Mark Siderits (2016), to name only a few who have persuasively demonstrated that much of classical Buddhist philosophy of mind rejects foundationalism in general and the Brahmanical àtmavādin doctrines of rebirth in particular. The Buddhist doctrine of nonself (anātman) explicitly rejects substance metaphysics and substance-based ontology, refuting the essentialism that drives many claims about body-mind dualism. Garfield, for example, has argued that dualism is a confusion which results in qualms about "correspondence or other reference or meaning-inducing relations, the relation of the self to the world, of mind to body, and the whole raft of confusions" and this confusion he argues is a consequence of "forgetting that the self or subject, to the extent that it is real at all, must be part of the world, not something standing over against it" (Garfield 2015, p. 275). Mark Siderits, also makes the point that a Buddhist, for whom all five aggregates components of human existence - are equally dynamic, subjected to quick changes, cannot be accused of adopting a form of dualism which claims to endure mental substance after the 
body ceases to exist (Siderits 2001, p. 308). Likewise, Arnold himself argues, since Buddhism emphasizes the relational and dynamic character of subjectivity, it appears to be immune to the accusation of asserting substance dualism (Arnold 2008, p. 1080).

The type of dualism Arnold attributes to Dharmakīrti appears to closely resemble property dualism. But, on a closer analysis, it is not. Property dualism, unlike Dharmakīrt's view of the irreducibly mental character of certain events, is a non-reductive physicalist claim in so far as it argues for an evolutionary emergence of mind and mental states from a complex organisation of purely material substance. Again, unlike Dharmakīrti’s view according to which mental events ontologically diverge from physical events, property dualist's claim that when physical events reached a certain level of complexity nonphysical properties emerged from the material events and non-reductively supervene upon those material events. After all, property dualism holds the view "that while there is one kind of (physical) substance, the mind not only has physical or behavioural-material-functional properties, but also nonphysical behaviourally-materially-functionally ineliminable and irreducible properties" (Jacquette 2009, p. 22).

Given the difficulties with both substance and property dualism we have good reason to believe that Arnold characterises Dharmakiriti's form of dualism as akin to even dualism indeed he suggests that the Buddhist philosopher Dharmakirti could consistently hold the view that "'persons' consist of simply in causally continuous series of events, and that the series of mental events, in so far as it continues after the death of the body, has indefinite temporal extension” (Arnold 2008, p. 1080).

On this line of reasoning even rebirth is rendered just a continuity of any series of mental events, allowing Buddhists like Dharmakīrti to account for karmic responsibility and their soteriological project.

Nāgārjuna's Arguments for Rebirth Theory: A Critique of Mind-Body Dualism 
In the remaining part of the paper, I will consider a detailed critique of Dharmakīrti's mindbody dualist argument from Nāgārjuna's Madhyamaka philosophical standpoint. The objections I present here, therefore, are predominantly drawn from Nāgārjuna's works on phenomenological causation and the philosophy of mind which have, thus far, received little or no attention in the literature. The cautious approach that academic studies of Nāgārjuna have taken thus far with respect to these works may be understandable. This is as amongst various topics that these works are concerned with is a detailed account on birth-death (the so-called rebirth theory) one of the "damned topics" in the philosophical studies of Buddhism. ${ }^{2}$ Still haunted by the Cartesian ghost story, we retain a tendency to lump all rebirth stories into one big Cartesian dualistic basket. Gilbert Ryle's provides a groundbreaking exorcism of the Cartesian ghost, labelling the official doctrine as "The dogma of the Ghost in the Machine" (Ryle 2009, p. 5). His claim to have snuffed it out as “one big ... category-mistake" (Ryle 2009, pp. 5-6), I suppose, did not have the extent of influence he expected. Indeed, the method Hayes employs in his analysis of Dharmakīrti's concept of "rebirth" demonstrates the extent to which we are, even as modern academics, still in someway "wedded to the dogma of the ghost in the machine" as Ryle righly tells us (Ryle 2009 , p. 21). More problematically, we should avoid readily projecting the dogma of mindbody dualism sweepingly onto Buddhist philosophers who may have never held such a commitment. Nāgārjuna is a good case in point. tucked away in his neglected works (see references for the details) is hidden some of the groundbreaking Mādhyamika insights into understanding and appreciating a radical Mādhyamika account of rebirth, phenomenology and the philosophy of mind, providing us the case for a completely different way to conceive of what rebirth entails. I hope to bring into discussions some aspects of Nāgārjuna's radical insights in order to challenge the common assumptions we have about what rebirth necessarily entails (as exemplified by Dharmakīrti's account). It turns out that rebirth, on 
Nāgārjuna's account, is nothing like what we imagine it to be, and lacks the commitments Hayes alleges Dharmakīrti must make.

I will now turn to the premises in Dharmakīrti's argument to consider specific objections. I will do this turn by turn in the interest of integrating the critical insights Nāgārjuna brings to bear upon his own conception of the rebirth. Through this dual method consisting of a critique of the rebirth theory entailing mind-body dualism and a defence of the rebirth theory that eschews any commitment to such dualism, I hope to reinforce insights behind Nāgārjuna's nondichotomous and non-substantialist philosophy of mind.

\section{My body does not survive after death}

The first premise in Dharmakīrti's argument states that body does not survive after death. The obvious assumption in this premise is that Buddhism is dualistically reductionist about persons, which is to claim that a person is reducible to two distinct entities: mind and body, and the death of person annihilates only the body, whereas the mind remains intact and persists. There are number of problems with this premise. For a start, in the Commentary on the Verses on Rice Seedling (Śālistambaka-vistarākhyāțīkā ŚVṬ), Nāgārjuna argues that name-form (nāma-rūpa) survive or fall together like sheafs of reeves leaning against each other. The name-aggregates - feeling (vedāna), perception (sai்jūā), conditioning factors

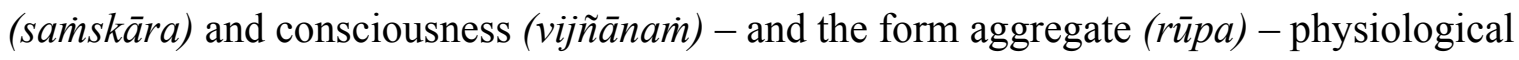
processes - are mutually dependent, one cannot exist without the support of the others. To explain the argument differently, name-form (nāma-rūpa), according to Nāgārjuna, consists of the five sensory consciousnesses and the defiled mental consciousness (kleśamayam manah) operating in conjunction with the four great elements (caturmahābhütāni) interdependently supporting each other in the manner of sheaves of reeds (nadakalāpayogena) (ŚVT 27: mDo 'grel Nge 39a). The reason behind putting together the näma-rūpa as a compound term is precisely to reflect the fact that each person is a coherent 
and inseparable unity of the physical aggregates and non-physical aggregates by virtue of mutually interdependent phenomenological causation.

Death, Nāgārjuna argues, signifies the transient and unstable nature of the nāma-rüpa aggregates as produced phenomena. While Nāgārjuna does speak of death both as the end of an individual life span, he more crucially speaks of death as an event occurring at each moment: one set of nāma-rüpa aggregates cease as the conditions passing out of existence even as another set of namma-rüpa aggregates arise. In either sense, death is only part of the law of impermanence and it does not represent an abrupt interruption or annihilation of life or the rūpa aggregate, independent of the nāma aggregate. While Hayes may be correct in claiming that death for Dharmakīrti occurs at the end of life, but to ignore the more significant philosophical point at stake is to misrepresent what lies at the heart of Buddhist philosophy of mind, the theory of death and dying. Nāgārjuna speaks of death as occurring at every moment. At each moment, as one causally dependent set of nāma-rūpa aggregates passes away another set of nama-rūpa aggregates arise. In this sense, death is simply the very ontological modifications taking place in nāma-rūpa aggregates every moment, making possible the very existence of the aggregates as they actually are. Dharmakirti's claim that death is a sudden event that annihilates the body, without affecting the mind, is therefore, problematic.

Thus, for Nāgārjuna, death - or the end of life - is a form of change that is not radically unlike the kind of change that takes place for everything at each moment. According to Nāgārjuna, both nāma-rūpa die together during death and another nāma-rūpa is born. But the two are not the same näma-rüpa, nor are they entirely separate. They are related in that they are part of a continuum - and 'conventionally' we can designate the organism as the continuum bearer. By one nāma-rūpa we perform our actions and by these actions we are born as another nāma-rüpa. One nāma-rūpa finds its end in our death, another 
nāma-rūpa takes birth from it. But the subsequent birth of namma-rūpa is the conditioned result of the previous nama-rūpa which is responsible for committing the actions under the influence of the afflictive defilements. When the näma-rūpa aggregates are not released from this conditioned existence, they are re-born in saṃsāra.

For Nāgārjuna it is important to note that death performs dual functions: death may bring to an end one type of namma-rūpa (at the macro level), but it causes, simultaneously, the birth of another set of namma-rūpa that invariably exists as the subtle nāma-rūpa aggregates. Candrakīrti cites the Daśäbhūmi-sūtra which says, "Death also involves two activities: it destroys the compounds and it provides the cause for an unbroken continuum of ignorance" ( $d B u m a$ 'a 59b). Candrakīrti argues, death's two activities are however not substantially distinct. Death destroys the unity of corporeal compounds, at the same time that it sets in motion the birth of a renewed nāma-rūpa complex that sustains the unbroken continuum of phenomenological flux - what we call 'person' or 'self'. In the Yuktiśāștīkāvṛtti (YŚS 20) and the Prasannapadā (PP) Candrakīrti argues that death is a cause of another set of disintegrating nāma-rūpa, analogous to the exhaustion of the butter and the wick acting as a cause of the extinguishment of the butter-lamp. According to this view if a causally produced death can arise from its conditions, its continuum sustained by the disintegrating subtle nāmarūpa too must solely depend on its conditions - death. For Candrakīrti death, since it is an event, must have a cause, therefore it is not an intrinsic disintegration or the annihilation of the aggregates ( $P P$ VII.32: $d B u m a$ 'a $59 \mathrm{~b})$. Just as it is not possible for a well-protected butter-lamp to die out without fully consuming its oil and wick. It is not the case that death is intrinsically annihilating, argues Candrakīrti (YŚV 20: dBu ma Ya 15b).

For a similar reason in ŚVṬ 41 Nāgārjuna makes the argument that rebirth follows the principle of non-annihilation (nocchedatah). According to this principle the nāma-rūpa aggregates that constitute the phenomenological structure of a person do not become manifest 
from the previous annihilation of the aggregates on the edge of death nor without a cessation of the aggregates on the edge of death. That is, the causes of rebirth are not interrupted or annihilated by death because the psychophysical aggregates partaking of birth do not arise from the final aggregates of death (māraṇantikeșu skandheșu) that have already ceased (pürvaniruddheșu), as this would imply birth without a cause, which is incoherent. Nor do the aggregates of birth arise from the aggregates of death that have not yet ceased (aniruddheșu), as that would imply birth from an eternal cause which is equally incoherent from Nāgārjuna and Candrakīti's standpoint. But when the aggregates of death cease (nirudhyante), at that very moment, argues Nāgārjuna, the aggregates partaking of birth arise like the ascending (unnāma) and descending (avanāma) beams (daṇda) of a scale (tulā) (ŚS 41: mDo sde Ma 190b-191a). ${ }^{3}$

Thus, death is not an annihilation of the body. Nāgārjuna supplies us with two key reasons why he thinks, as it is for Candrakīrti in the Sixty Verses on Reasoning (Yuktiśāștīkāurtti YŚSV), that death is not an annihilation. Firstly that death, since it is a causally conditioned event, is an effect as it is an effect of another set of preceding nāmarüpa aggregates that is disintegrating. Secondly that death, since it is a causally conditioned event, is a cause as it causes the birth of another set of future nāma-rūpa aggregates to arise. In contrast the reductionists Naiyāyika ${ }^{4}$ and Sautrāntika ${ }^{5}$ assert that death is an intrinsic destruction, therefore annihilation of the rūpa - form-aggregate and the continuation of nāma - mental aggregates (Candrakīrti, YŚV.20: dBu ma Ya 15b). So, for both the Sautrāntika and the Naiyāyika, the death (disintegration) of the aggregates is entirely different from the birth (arising) of the aggregates. The death of the aggregates is an absence, while the birth of the aggregates is a presence (existent), with a cause (in the case of the Naiyāyika) or without a cause (in the case of the Sautrāntika), acting upon the death. 
For non-reductionist Nāgārjuna and Candrakīrti, however, the disintegration of the aggregates is itself an activity of the aggregates that sustains its existence: the two are not different. Thus, disintegration of the aggregates is not incompatible with its existence, and disintegration has a cause and it produces an effect. For whatever exists is causally effective. Therefore, for Nāgārjuna and Candrakīrti death, is similar to any other change in that it is causally productive; it produces an effect and it arises from causes, hence it is not an annihilation.

It is problematic, thus, to claim that the Buddhist theory of death entails the destruction of rūpa-aggregate, but not nāma-aggregate BECAUSE buddhist death doesn’t entail annihilation but transformation - and this applies as much to both nama and rupa aggregate.

2. My mind survives the death of the material body

In Premise 2 Dharmakirti claims that the mind survives the death of the material body. It is obvious Hayes' claim is operating on the same assumption as seen in Premise 1, that is, that on Dharmakīrti's view, mind and body are separate and only mind persists or "survives" the death whereas the body does not. To claim that the mind survives death is to assert that the mind persists after death, and it would entail reification from the Mādhyamika standpoint. As we shall see both Nāgārjuna and Kamalaśîla show that the claim that mind is persistent is incoherent in the context of the Buddhist account of birth and death. Rebirth in the Buddhist context, Nāgārjuna proposes, is a simple continuation of a nāma-rūpa complex (and I will return to this point at the end of the paper for a detailed consideration), not the persistence of mind, and that is the heart of the argument Nāgārjuna is making. Without separate and persistent mind and body, we don't get the mind-body dualism to which Hayes claims Dharmakīti is committed. Moreover, Kamalaśîla's arguments from his Light of the Middle 
Way (Madhyamakāloka, MA) shows a persistent mind is causally inert, as it does not have the causal efficacy to produce karmic effects either:

- $\quad$ successively (krama),

- non-successively (akrama) or

- $\quad$ simultaneously (tāvat).

First, according to Kamalaśîla, a persistent mind lacks the causal efficacy to produce any effect on the body successively, for a persistent mental cause would be, by definition, constantly, and uninterruptedly causally active on the body, assuming that they can interact. A persistent mental cause's efficacy is entirely unshackled - not contingent upon other conditions - and so in principle, a persistent mind should produce its body perpetually. In which case body, would also exist forever; therefore, rebirth would make no sense, as it would be effectively annulled. If, however, a persistent mind produces its rebirth successively, or intermittently (Dharmakīrti's rebirth theory seems to rely on either of these possibilities) thus affecting the body this way, there is an inconsistency problem. Successive rebirths can be produced only by non-persistent causes because the timing of their succession is governed by necessary but equally changing causal conditions. But the continuous causal processes which seem to underpin rebirth are impossible if it is true that the mind which causally produce the future body is itself persistent (Kamalaśîla, $M A$ : $d B u$ ma $S a$ 192a).

Dharmakīrti could reply to the above objection by claiming that a persistent or surviving mind does depend upon such other conditions. Even that would, on Kamalaśîla's argument, deliver him into other inconsistencies. Because the cause is a persistent mind, the conditions upon which it depends would also be persistent, and the problem would repeat itself. The inability to explain causal succession (which is necessary to support Dharmakīrti's rebirth theory) would just be shifted one link down the causal chain. On the other hand, accepting a persistent mental cause's dependence on non-persistent conditions to produce 
rebirths successively would be an admission of its non-persistence - because a mind is a conditioned phenomenon it cannot endure longer than the conditions that give rise to it, let alone after death.

In either case, it makes no sense for a persistent mind to depend upon supporting conditions, which are all changing to produce rebirths. Either one has to posit that the conditions also are persistent and we are no closer to an explanation of successive rebirths, or one has to admit that mind is non-persistent. Either way, the claim that rebirth requires a persistent mind is undermined (Kamalaśīla $M A$ : dBu ma $S a$ 192a).

Second, likewise, it makes no sense to claim that a persistent mind could produce rebirth non-successively, that is, without the need of successive causal change. A nonsuccessive rebirth as an effect could be a theoretically valid solution to some logical problems posed by a persistent cause, but the problem is that such non-successive effects are not found anywhere empirically or phenomenologically outside the domain of theory. Phenomenological effects are observed to occur intermittently, in succession. In the case of rebirth theory founded on the mind-body dualism which posits a persistent mind as its cause, the arising of rebirth (as an effect) inevitably has to proceed from its persistent mind as its cause. But this type of causation is not available for the claim according to which rebirth occurs due to a persistent mind. Without the mind undergoing change or cessation, rebirth as an effect cannot arise, but this phenomenological fact is what, according to Kamalaśîla, makes rebirth possible. After all, it is what entails successive causal change which allows the occurrence of rebirth.

For causation to continue beyond a single cause and effect, something must succeed it. Successive causal change is thus the very basis of "causation" itself. Causation simply is the succession of causes and effects, and succession requires cessation. But the cessation of a persistent mental cause, as we have repeatedly seen, is unreasonable, for persistence is by 
definition unceasing. And if it were to cease, the mental cause would have to give up its claims to have a persistent nature; one must necessarily accept it as non-persistent like the body. Thus, Kamalaśîla concludes, a persistent mental cause is no more able to produce rebirth as its effect non-successively than it is successively (Kamalaśîla $M A$ : dBu ma $S a$ 192b-193a).

Finally, persistent mental causes lack the causal efficacy for simultaneous production (tâvattad yujyate) of rebirth as its effect, for an effect simultaneous to its cause would never stop being produced. It is the nature of a persistent cause to cause things, and a cause which continues to exist past the moment of its effect's production would keep causing. A productive persistent mental cause, then, would create an absurd feedback loop of endless production of rebirths. Again, we cannot deny this function without denying the mental cause's persistent nature. A mental cause which would cease causing after causing its rebirth (as an effect) would have to renounce its claims to have a persistent nature.

Thus, it is clear from the above arguments that a persistent mental cause is both logically incoherent and phenomenologically impossible. A persistent mental cause is precluded from producing rebirth as its effect successively, non-successively and simultaneously. Since a rebirth can only take these three forms, the failure of the persistent mental cause to demonstrate its causal competence in a single one of these forms disqualifies a persistent mental cause from productive power entirely (Kamalaśîla $M A$ : dBu ma $S a$ 193ab).

Against the mind-body dualism according to which a mind survives the death of the material body, Nāgārjuna also deploys two arguments. The first argument is from the principle of non-persistence (na śäśvatato) according to which the aggregates on the edge (antikāh) of death (marana) are one thing and those partaking of birth are quite another. Those final aggregates partaking of death are also not identical to those aggregates partaking 
of birth. The causes which produce (upapatti) are precisely the ones which destroy (vināśakāh). The causes that destroy are also just the ones which produce. Since this is the case, when the final (antikāh) aggregates of death (marana) likewise cease (nirudhyante), the aggregates partaking of birth arise (prädurbhavanti). Therefore, causes of rebirth including consciousness are not persistent (na śáśvatatah) (ŚVṬ 63: mDo 'grel Nge 50a). Therefore, it is false that the same mind survives the death of the body.

It is against this mind-body dualist claim that Nāgārjuna's argument from the principle of non-transmigration (na samkrāntitah) is also primarily directed. According to this argument, in phenomenological causal process, there is no dharma ${ }^{6}$ anywhere $(\text { kvacid})^{\prime}$ that goes from this world (asmāllokāt) to the next; nevertheless, from the collocation of causes and conditions, there is the effect of karma, appearance (abhyeti) (ŚK 56: mDo 'grel Nge 20b). In the Commentary on the Heart of Dependent Origination (Pratītyasamutpādahrdayavyākhyāna PSHV) an interlocutor raises this question: so, is it the case that there is no real sentient being that transmigrates (saíkrāmati) from this world (asmāllokāt) to the next world (paralokaì)? Nāgārjuna's response is emphatic. He says that there is "nothing" whatsoever that transmigrates (na sainkrāmati), from this world to the next world, including even a "minute particle" (sūkșmo'ṇurapi). He says, it is just that "from ‘exclusively empty’ (śūnyebhya) phenomenon arise only ‘empty phenomenon’ (s'ūnyā dharmāh)" (Nāgārjuna PSHV: dBu ma Tsa 148a). The empty causes consist of afflictions (kleśa) - ignorance, craving and clinging - and karmic actions (volitional actions and becoming). These causes apparently lacked (rahitebhyo) both "I" and "Mine" - the selfhood $(\bar{a} t m a)$ and the ownership by such selfhood (ätmìya) - and yet from the nexus of these empty causes arise dependently designated "empty effects" (phalakalpitāh śūnyāh of the so-called "birth" that lacked a selfhood (Nāgārjuna PSHV: dBu ma Tsa 148a). 
It is noteworthy that Nāgārjuna just says "birth," not "re-birth." This is a significant point because for the latter to be possible there has to be a selfhood or consciousness that transmigrate from the former to the future life without undergoing a substantial change. When there is no transmigration of any entity, there is just birth, but technically, no rebirth. The lack of the selfhood is true even in the case of a birth (as an effect) which is produced from the mutual dependence of the causes and conditions that lacked the selfhood and those that lacked the ownership by such self. Therefore, transmigration is not possible: hence rebirth is not possible. It it not possible for the entities that intrinsically lacked selfhood (svabhāvato'nātma) and those which arise (prabhavanti) from those entities that intrinsically lacked selfhood to be born again, or to repeat their existence (Nāgārjuna PSHV: $d B u$ ma Tsa 148a).

However, there is birth because there are empty karmic causes from which arise the empty effects. That is, there is nothing whatsoever within the phenomenological structure of a person including a consciousness that transmigrates from this world to another world. Therefore, there is nothing that is reborn. In birth, there is only the appearance of the fruit of karma in virtue of the non-deficiency of causes and conditions. Nāgārjuna furnishes his argument with a range of allegories with these he illustrates the way in which the entities that intrinsically lacked selfhood arise from those entities that are themselves intrinsically empty of such selfhood.

svādhyāyadīpamudrādarpaṇaghoṣa'rkakāntabījāmlaiḥ| skandhapratisandhirasan̈kramaśca vidvadbhiravadhāryau \|

Like a recitation, a lamp, a mirror, a seal, a magnifying glass, a seed, sourness, or a sound, so also with the conception of the aggregates - the wise knows they are not transmigrated (Nāgārjuna Heart of Dependent Origination (Pratitīyasamutpādahṛdaya PSH, dBu ma Tsa 146b). 
We shall consider here, given space constraints, only the first example: an oral recitation (and shall turn to some other examples in the concluding part of the paper, later). The teacher first recites a verse, and the students repeats it after her. In this process, the teacher's recitation causes the student's ability to repeat it. Still it is not the case that the teacher's ability transfers to the students. Nor is it the case that the student's ability comes from somewhere other than the teacher. If it were the former, the teacher would be left deprived of her ability: she would not be able to recite the verse again after that, the problem of annihilation would occur. If it is the latter either the student's ability had to come without a cause (ahetubhütatvāt) or it had come from an entirely unrelated cause. In which case, the problem of causelessness would occur. Both these alternatives are unreasonable, however. Just as the teacher's recitation causes the student's ability to repeat, despite there being no transference of the teacher's ability to the students, in the same way, causes give rise to their effects without there being the transference of the causes into the effects. Therefore, the problem of persistence (śâśvata doṣaḥ) does not arise (Nāgārjuna PSHV: dBu ma, Tsa 148a). Just as the student's ability neither arises from another cause (other than the teacher's recitation), nor is it without a cause, similarly the effects do not arise from another cause (unrelated to the effects) nor without a cause. This way Nāgārjuna resolves both the problems of persistence and causelessness. It is clear that the teacher's recitation causes the student's ability to repeat it. It is however not possible to articulate whether the student's ability to repeat is either identical to or entirely different from the teacher's recitation - the relationship between the two is neither one of strict identity nor are they entirely distinct. In the same way, although birth arises from karma, it is not reasonable to describe the causal relationship between birth and these karmic causes and conditions in terms of either strict identity or strict difference (Nāgārjuna PSH: dBu ma Tsa 148ab). 
3. Therefore, rebirth occurs since my mind can be associated presently with one body and in the future with another

In Premise 3, drawing upon Premise 1 and 2, Dharmakīrti makes the claim that rebirth occurs because mind can be associated presently with one body and in the future with another. This conclusion operates on the assumption that there is a transference or transmigration of the same mind during rebirth without which, according to Hayes, Dharmakīti could not account for rebirth. Dharmakīrti's claim would be true if Premise 1 and 2 are true, since Premise 3 is found on the conclusion of the first two premises. But since we have already shown that Premises 1 and 2 are both incoherent, it follows; therefore, that Premise 3 is also incoherent. Moreover, the case that Nāgārjuna raises for viewing the relationship between the body and mind in non-dichotomous terms, is evident from the way in which he presents the phenomenological structure of what is to be a person. A person is invariably defined as a phenomenon designated in dependence upon the five aggregates which Nagarjuna argues are inextricably interwoven with each other as a unified phenomenological continuum. The five aggregates mutually cause each other, arise from each other, and cease with the ceasing of the other. Consequently, no single aggregate can be ontologically isolated from the rest; the five aggregates invariably dovetail in the phenomenological constitution of a person. While prima facie, we may assume that the so-called rūpa-aggregate constitutes a person's physical body, in actual fact, the rūpa-aggregate does not have enough content to constitute the body of an embodied person: body is not purely physical (like a piece of computer hardware), it must be a sentient to become and exist as it is.

The argument goes in the other direction as well. The so-called mental-aggregates that, prima facie, constitute a person's mental states, in actuality, do not have what it takes to constitute the mental processes of an embodied person: mental states are not purely nonphyiscal, they must be embodied. An interdependent existence of the nāma-rūpa aggregate 
implies that there cannot be any mental episode that is purely non-physical or immaterial just in the same way that there cannot be a physical body of a person which is entirely physical. The kind of pure consciousness we see in the Sāmkhya or Cartesian systems is simply an impossibility in Nāgārjuna's philosophy of mind. Not surprisingly, the body-mind complex is invariably and reciprocally presented as co-arising and mutually dependent nämarūpa complex as a one-fold factor, one of the twelve factors of dependent origination. ${ }^{7}$

Nāgārjuna argues that birth arises from the complex combination of causes and conditions and from the absence (vaikalyād) of a creative agent (kartr) and the absence (aviyogatah) of the subjectivity of I-grasping (ahamkār). This process of phenomenological causation, argues Nāgārjuna, applies to all causally conditioned processes: the arising (utpāda), abiding (sthiti), and perishing (vināśāa) of all dharmas (ŚK 54cd-55: mDo 'grel Nge 20b). In this causal process, there is no dharma anywhere (kvacid) that goes (gantā) from this world (asmāllokāt) to the next (paraì); nevertheless, from causes and conditions, there arises the effect (phalam) of karma (karmanah): appearance (abhyeti) (ŚVT 56: mDo 'grel Nge 48b).

While there is nothing whatsoever that goes from this world to the next and consequently, no rebirth (janmābhāso) as such, yet there is the appearance of birth, the effect of karmic activity in virtue of the non-deficiency of causes and conditions, as when there are insufficient causes and conditions (for instance fuel and a flame) fire does not ignite and when these causes and conditions are present fire ignites (ŚVT 56: mDo 'grel Nge 49b, cf. ŚK 63: $m$ Do 'grel Nge 20b).

\section{Therefore, mind and body are distinct}

The conclusion of the mind-body dualism argument is that, mind and body are distinct which Hayes goes on to attribute to Dharmakīrti. As I have shown the arguments from Nāgārjuna demonstrates that this conclusion does not hold because all the premises Hayes uses to 
support it are false. Rebirth does not entail annihilation of the aggregates; hence it is not the case that death annihilates the body. Rebirth does not entail persistence of the aggregates, hence it is not the case that my mind survives death. Therefore, it is not the case that the same mind I have now can associate presently with one body and in the future with another. Therefore, the conclusion that Buddhist theory of rebirth is premised upon body-mind dualism is incoherent.

\section{Implications}

Hayes is right to claim that Dharmakīrti affirms rebirth and seeks nirvāṇa - its cessation. He is also right to argue that if there is no rebirth, then the very goal of attaining nirvāna, understood as the cessation of rebirth, becomes almost utterly meaningless. But Hayes is wrong to claim that, in virtue of accepting rebirth, Buddhism must endorse mind-body dualism. As I have shown, using Nāgārjuna's account of rebirth, there is no necessary entailment between the premises Hayes employs and the conclusion he drives home. Nāgārjuna explicitly argues that the dualistic illusion of subjectivity and objectivity, mind and body are nothing more than conceptual fictions sustained by confusion of the basic phenomenological structure of who we are as persons. Indeed, there is, strictly speaking, "no rebirth" understood in the sense of the same mind being born again, and again because there is no single event whatsoever that repeats itself in the causal chain.

Let us ask this question as a way to bring closure to the analysis we have undertaken thus far: what, then, is Nāgārjuna's own position on rebirth and why does his theory not entail mind-body dualism? As we have observed, Nāgārjuna responds to this question by arguing that what we usually take to be rebirth - the appearance of persistence over time - is in fact only a continuum of momentary, causally dynamic successive events constituting mind-matter (nama-rūpa) complex of the five aggregates which we nominally refer to as 
"person," or "self." This continuum, on Nāgārjuna's view, is both temporally and spatially causally effective in two ways. The successive nama-rüpa continuum is synchronically causally effective amongst the present aggregates because they simultaneously support and cause each other's existence, like the sheaves of reaves leaning against each other. The successive nama-rūpa continuum is diachronically causally effective amongst the successive moments of the five aggregates. This is so because the preceding moments produce the subsequent moments resemble each other sufficiently, such that they can serve as the basis of dependent designation - allowing us to refer nominally with a single term of reference: calling it the "same person."

This causal continuum of the namma-rūpa complex, often confused with persistent personal identity, as exemplified in Dharmakīti's mind-body dualist thesis, is nothing more than a causal chain itself, where there is no single substance found anywhere independent of social conventions which we can identify as the reality of a person. The continuum of the five aggregates is designated as a conventionally real person, in that the continuum serves the pragmatic purpose of who we are as persons, explaining the principles of karmic responsibility and causation.

Thus, Nāgārjuna's conception of rebirth takes the middle path. It circumvents causal nihilism (ahetu-vādo) which denies the existence of a causal continuum of nāma-rūpa complex on the ground that there is no persisting substance from moment to moment, and thus no truthmaker for true personal identity. Yet it also circumvents reificationism (nityavādo) which assert that there exists a persistent and reductive entity (such as âtman of the Naiyāyikas, ālayavijnāña of the Yogācāra, prāpti of the Vaibhāṣika, the continuum of mental consciousness of the Sautrāntika and the Svātantrika) that is supposed to be a temporally and spatially extended continuum exemplifying what a person is. By contrast, Nāgārjuna uses a wide range of analogies such as a flame transferred from lamp to lamp 
(even though nothing is actually transferred) to explain the continuum across lives, instances or births, "stressing the role of causation, without any identity, and the fact that the talk about a flame that is transferred is nothing but a façon de parler", as Garfield puts it $(2015, \mathrm{p}$. 47). There is no real flame to be transferred, although it appears that way, there is only a sequence of uninterrupted causally related events that serve as the basis of designation: "flame" and "transference." Similarly, rebirth's basis of designation is a causal continuum of the cluster of the five aggregates, but not a continuum of any one individual aggregate in the manner in which the Buddhist reductionist sought to reductively identify it. That is, the continuum of the cluster of nama-rūpa complex is causally responsible for constituting the basis for our conception as continuing entities through the process of rebirth with a specific pronouns and names. But none of the microphenomenological aggregates is the referent of the name "rebirth," just as none is the referent of the names: 'I', 'me', 'myself,' 'mine', or even 'you', 'yourself."

Nāgārjuna argues that we can confirm this phenomenon of causal continuum from some of the well-known epistemic resources: perception (pratyakșa), inference (anumāna) and testimony (viśvastāgama) (ŚVT 56: dMo 'grel Nge 48b-49a). The causal continuum of näma-rüpa complex functions like the reflection of a face seen in a well-polished mirror. The reflection inside the mirror is indeed not transferred (samkrämitam). The face and the mirror are devoid of any intentional thoughts (āvikalpanam) of mutually working together to form the reflection of a face: they are bereft (vihinam) of agent (kartr) and action (kriyā). Still there is no causal nihilism or interruption in spite of the absence of agent and action. There is still the appearance of a face in the mirror because of the non-deficiency of causes and conditions. In just the same manner because causes and conditions are not deficient, there is the manifestation ( $\bar{a} v a b h \bar{a} s a n a m)$ of the continuum as birth (utpād), the fruit of karma, based 
on the progression of deeds previously (pūrva) accumulated and presently being accumulated (ŚK 57-58: dMo 'grel Nge 20b).

The causal continuum operates like the distant (dürasthaś) moon (candramaṇalaim) which wanders thousands of leagues above and yet again we can observe the moon's reflection (candrasya pratibimbaim) inside of a small water container. There is no transference of the moon from its location (tasmātsthānāc), and yet there is the appearance of the moon disk in the pool of water because of the non-deficiency of causes and conditions. In the same manner, the continuum of nama-rūpa complex is sustained through impersonal activities of karmic forces (Nāgārjuna ŚK 59: dMo 'grel Nge 20b). There is nothing whatsoever in this causal continuum that persists and moves on from this world to the next and consequently no rebirth (janmābhāso) as such, yet there is the appearance of birth of the continuum, the effect of karmic activity in virtue of the non-deficiency of causes and conditions. As when causes and conditions are deficient, fire does not ignite and when causes and conditions are complete fire ignites (ŚVT 60: $d M o$ 'grel Nge 49b). Therefore, causal continuum of nāma-rūpa complex, Nāgārjuna argues, should always be understood as having two kinds of properties: lacks an agent (kartr) and lacks essence (sārah), upon analysis the continuum of person is hollow (tuccha) and empty (s'ünyā) of intrinsic nature (ŚK 63: $d M o$ 'grel Nge 20b). Accordingly, Nāgārjuna concludes that phenomenological continuum is (i) non-persistent (na śáśvatatah), (ii) non-interrupted (nocchedatah), (iii) non-transmigrated (na samikrāntitah), (iv) one which proceeds from a small cause (parīttahetuto) (abhinirvrttatah) a great result (vipulaphala) and (v) in which continuity (ānuprabandhataśceti) invariably resembles (sadriś) that of causes and conditions at play (Vaidya P.L. 1961. ed. ŚS 40: mDo sde Ma 190b).

Through a sustained phenomenological reflection (bhāvanāa) focusing on the nature of the causal continuum, Nāgārjuna argues, one progressively develops true awareness (viditvā) 
of the four noble truths (caturäryasatya) realising the causal continuum to be non-substantial (asāra), deprived of any substance-reality such as agent (kartrādirahito): hollow (riktas), trifling (tuccha), evanescent (anityatā), precarious (duḥkhatā), empty (śūnyatā) and selfless (nairātmya) (ŚVṬ 67: dMo 'grel Nge 52ab). Consequently, all causal continuum of persons and of phenomena are correctly recognised (vibhävane) to be no different from the functional operations of illusion, mirage, the city of gandharva, the wheel of a firebrand, an echo, the moon's image in water, the reflection of a face and the like. By means of this reflective experience (vibhāvane), one attains the ultimate freedom from the mistaken and dualistic perception of the object grasped (grāhya) and the subject grasping (grāhakatāim).
Abbreviations
YȘV Yuktișașthikavṛtti
PP Prasannapadā
MA Madhyamakāloka
ŚT S Sālistambakațīka
TSP Tattvasaimgraha-Pañjikā
PSH Pratītyasamutpādahṛdayakārikā
PSHV Pratītyasamutpādahrdayavyākhyāna
ŚK Ś́̄istambaka-kārikā
ŚVṬ Ś́listambakavistarākhyātīkā
ŚS Ś̃̄istamba-nāma-mahāyāna-sūtra,
AKB Abhidharmakośa \& Bhāṣya

\section{References}

Arnold, Daniel A. 2008. "Dharmakīrti's Dualism: Critical Reflections of a Buddhist Proof of Rebirth.” Philosophy Compass 3, no. 5: 1079-1096.

Arnold, Daniel A. 2012. Brains, Buddhas, and Believing: The Problem of Intentionality in Classical Buddhist and Cognitive-Scientific Philosophy of Mind. New York: Columbia University Press. 
Bodhi, Bhikkhu. 2000. The Connected Discourses of the Buddha: A New Translation of the Samyutta Nikāya. Vol. I \& II. Boston: Wisdom Publications.

Burley, Mikel. 2007. Classical Sämkhya and Yoga: An Indian Metaphysics of Experience. New York: Routledge.

Candrakīrti. Clear-word (Prasannapadā). Toh. 3860. bStan' 'gyur, sDe dge edition. dBu ma Vol. 'a, 1b-200a.

Candrakīrti. Commentary on the Sixty Verses on Reasoning (Yuktișașthikavrtti). Toh. 3864. bStan 'gyur, sDe dge edition. $d B u$ ma Vol. ya 1b-30b.

Descartes, René. 2013. Meditations on First Philosophy. LLC: Seedbox Press.

Garfield, Jay L. 2015. Engaging Buddhism: Why It Matters to Philosophies. Oxford: Oxford University Press.

Hayes, P. Richard. 1993. "Dharmakīti on Rebirth". In Studies in Original Buddhism and Mahāyāna Buddhism.Vol. 1 edited by Egaku Mayeda, pp. 111-129. Kyoto: Nagata Bunshodo.,

Hayes, P. Richard. 2013. "Why is Philosophy of Mind an Issue in Buddhism?” In $A$ Companion of Buddhist Philosophy, edited by Steven M. Emmanuel, pp, pp. 395404. Wiley-Blackwell.

Jacquette, Dale. 2009. The Philosophy of Mind: The Metaphysics of Consciousness. New York: Continuum International Publishing Group.

Kamalaśīla. Light of the Middle Way (Madhyamakāloka). Toh.3887. bStan 'gyur, sDe dge edition $d B u$ ma Vol. Sa, 133b-244a.

Kamalaśīla. Commentary on the Sūtra of Rice Seedling (Äryaśälistambakațīkā). Toh. 4001. bKa' 'gyur, sDe dge edition, mMo 'grel, Ji 145b5-163b4. 
Kamalaśîla. Commentary on the Difficult Points of the Verses on Compendium of Reality (Tattvasamgraha-Pañjikā). Toh. 4267. bStan 'gyur, sDe dge edition. Tshad ma Vol. Ze, 133b-363a.

Kher, V. Chitrarekha. 1992. Buddhism as Presented by Brahmanical Systems, Bibliotheca Indo-Buddhic Series No. 92. Delhi: Sri Satguguru Publications.

Macy, Joanna. 1991. Mutual Causality in Buddhism and General Systems Theory: The Dharma of Natural Systems. Suny Series in Buddhist Studies. Albany: State University of New York.

Nāgārjuna. Verses on The Heart of Dependent Origination (Pratītyasamutpādahrdayakārikā). Toh. 3836. bStan 'gyur, sDe dge edition dBu ma, Tsa 146b2-146b7.

Nāgārjuna. Commentary on the Verses of The Heart of Dependent Origination (Pratītyasamutpādahrdayavyākhyāna). Toh 3837. dBu ma, Tsa 146b7-149a2.

Nāgārjuna. Verses on Rice Seedling (Śälistambaka-kārikā). Toh. 3985. bStan 'gyur, sDe dge edition, mDo 'grel, Vol. Ngi, 18a3-20b4.

Nāgārjuna. Detailed Commentary on the Verses on of Rice Seedling (Śālistambakavistarākhyātịkā). Toh. 3986. bStan 'gyur, sDe dge edition, mDo 'grel, Vol. Ngi, 20b4-55b3.

Ñanananda, Bhikkhu. 2007. Samyutta Nikāya: An Anthology. Kandy: Buddhist Publication Society.

Phillips, H. Stephen. 2009. Epistemology of Perception: Transliterated Text, Translation, and Philosophical Commentary of Gannigeśa's Tattvacintāmaṇi. Delhi: Motilal Banarsidass Publishers Private Limited. 
Reat, N. Ross. 1993. The Śālistamba-sūtra: Tibetan Original Sanskrit Reconstruction. English Translation Critical Notes (including Pāli parallels, Chinese version and ancient Tibetan fragments). Delhi: Motilal Banarsidass Publishers Private Limited. Ryle, Gilbert. 2009. The Concept of Mind. New York: Routledge.

Schoenin. D. Jeffrey. 1995. The Śālistamba Sūtra and Its Indian Commentaries: Translation with Annotation. Wiener Studien Zur Tibetologie Und Buddhismuskunde Heft 35,1. Vol. 1 \& Vol. II. Wien: Arbeitskreis für Tibetische und Buddhistische studien Universitat Wien.

Siderits, Mark. 2001. "Buddhism and Techno-Physicalism: Is The Eightfold Path A Program?” Philosophy East \& West, vol. 51 (3) 307-314.

Siderits, Mark. 2016. Personal Identity and Buddhist Philosophy: Empty Persons. New York: Routledge.

Mahāyāna Sūtra on of Rice Seedling (Śāistamba-nāma-mahāyāna-sūtra). 196. In Mahāyāna-sūtra-saṁgrahah Part 1 edited by Vaidya, P.L. Darbhanga: The Mithila Institute of Post-Graduate Studies and Research in Sanskrit Learning. (H 211) Lhasa edition. mDo sde. Vol. 62. Ma 190b-191a.

The Cowherds. 2011. Moonshadows: Conventional Truth in Buddhist Philosophy. New York: Oxford University Press.

The Cowherds. 2016. Moonpaths. Ethics and Emptiness. Oxford: Oxford University Press. Vasubandhu. Abhidharmakośa \& Bhāṣya of Ācārya Vasubandhu with Sphutārthā Commentary of Ācārya Yaśomittrā. Dwārikā Dās Sāāstri, Swāmī (ed.). Vols. $1 \& 2$. Varanasi: Bauddha Bharati. 
${ }^{1}$ I am grateful for Professor Jay L. Garfield's and the blind assessor's insightful and incisive criticisms on my earlier draft which helped improve the quality of the paper significantly. I am equally grateful to Julien T. Wiltshire for carefully editing of the article.

${ }^{2}$ Karin Meyers's phrase used in her presentation for November 2016 AAR, San Antonio. ${ }^{3}$ Reat (1998, p. 68) and Schoening (1995, p. 324) offer two slightly different ways of rendering the verse in English. Note that the Sanskrit words unnāma, translated here as "ascending," and avanāma translated here as "descending" are both verbs indicating activities or processes of the ascending and descending the beams (danda / mda 'i) of a scale (tulä / srang). Unnāma means "the act of bending upwards, raising or rising upward. Avanāma means "bending or bowing." The Tibetan terms mtho and $d$ man used here as the equivalents, however, are adjectives. They describe the location of the beams, but they do not adequately capture the emphasis given on their activities (Cf. ŚK 63: mDo 'grel, Nge 50a).

${ }^{4}$ Vācaspati Miśra says, when explaining us the Naiyāyika's account of disintegration, it is an absence or non-existence even though disintegration itself, unlike the Sautrāntika, has a cause. (Kher 1992, p. 169).

${ }^{5}$ In the Abhidharmakośa-bhāṣya (AKB IV.2b-3b) Vasubandhu presents the Sautrāntika's position of momentary disintegration as both causeless and effectless. (Vasubandhu, AKB IV.2b. Skt. ed. Swāmī Dvarīkā Śāstri). Śāntirakṣita makes the same point which is elaborated in Kamalaśîla’s Tattvasamigraha-Pañjikā TSP. See Kamalaśîla, TSP VIII. 388. Skt. ed. Svāmi Dvarīkā Śāstri.

\footnotetext{
${ }^{6}$ Nāgārjuna makes it clear that the dharma in this context includes everything there is. "The dharmas are the aggregates (skandha), elements (dhätva), causal sources (āyatana), and
} 
interdependently arisen (pratītyasamutpāda) and the like (ādayo)" (Nāgārjuna ŚVT 56: mDo 'grel Nge 48b).

${ }^{7}$ We have two powerful Pali Canonical sources marshaling this line of reasoning. See SN II.67.7, Bodhi 2000, p. 607, Ñanananda 2007, p. 38n; DN II.32, Macy 1991. 